\author{
GIADA d'ERRICO $(*)$ - SHERIDAN LOIS WOO $(*)$ - NADIA LOMBARDI $(*)$ \\ GELSOMINA MANGANIELLO $(*)$ - PIO FEDERICO ROVERSI $(* *)$
}

\title{
ACTIVITY OF CHESTNUT TANNINS AGAINST THE SOUTHERN ROOT-KNOT NEMATODE MELOIDOGYNE INCOGNITA
}

\author{
(*) University of Naples "Federico II", Department of Agricultural Sciences, via Università 100, 80055 Portici, Naples, Italy. \\ (**) Consiglio per la ricerca in agricoltura e l'analisi dell'economia agraria - Research Centre for Plant Protection and \\ Certification (CREA-DC), via Lanciola 12/A, 50125, Firenze, Italy. \\ Corresponding author: giada.derrico@unina.it
}

d'Errico G., Woo S.L., Lombardi N., Manganiello G., Roversi P.F. - Activity of chestnut tannins against the southern rootknot nematode Meloidogyne incognita.

Studies on the effects of tannins on plant-parasitic nematodes are few. A new formulation of a hydrolysable tannin extracted from chestnut $\left(\right.$ SaviotaN $\left.^{\circledR}\right)$ was tested for efficacy in controlling Meloidogyne incognita. Therefore, in vitro and pot experiments on tomato were performed to investigate the nematicidal activity of tannin aqueous solutions at different concentrations on $M$. incognita. In the in vitro experiment the following concentrations of tannin at $0.30,0.40,0.50,0.75$, $1.00,1.25,1.50 \mathrm{~g} \mathrm{~L}^{-1}$ were tested for their effect on the nematode. The second-stage juveniles (J2s) immobility increased with increasing concentration and exposure time. All tested tannin concentrations were effective to reduce viability from about 45 to $70 \%$ after 10 days of exposure, in comparison to the treated and untreated controls. The immobile J 2 s recovered their mobility over time after rinsing and transferring them in water, showing a nematostatic activity of tannins. In the pot experiment, tannins, as aqueous solutions at rates from 0.30 to $1.50 \mathrm{~g} \mathrm{~L}^{-1}$, were applied to soil at three different application times (1: only at transplant; 2 : at transplant, two weeks after transplant and repeated every seven days; 3 : at transplant and two weeks later). The activity of tannins was compared to treated and untreated controls. Tested rates mostly repeated were effective to control nematode attack in comparison to untreated control. The height of treated plants was not significantly influenced by the different applied rates of tannins, whereas nematode population density and root galling index were affected by repeated application times. No visual symptoms of phytotoxicity were detected. The use of SaviotaN ${ }^{\circledR}$ appears promising for the control of $M$. incognita in sustainable agriculture of short-term crops and/or when nematode population densities are low and as a supplement to other chemical treatments.

KeY WorDs: Root-knot nematode; Meloidogyne incognita; Tomato; Hydrolyzable tannins; SaviotaN ${ }^{\circledR}$

\section{INTRODUCTION}

Root-Knot Nematodes (RKN) are the most common and widespread group of nematodes in the world causing dramatic yield losses to a wide range of crops. The simultaneous presence of RKN and plant pathogenic fungi may cause synergistic damages (RAGOZZINO \& D'ERRICO, 2011). The European Union has deeply restricted the use of pesticides on agricultural crops focusing the attention on enviromental safety, human and animal health (GHORBANI et al., 2008). It has been estimated that the global damage caused by pesticides reaches $\$ 100$ billion every year (Koul et al., 2008), and a significant percentage is represented by nematicides (RENČO et al., 2014). Alternative strategies for the control of RKN are needed to limit their economic and environmental impacts. Various plant species or compounds extracted and exuded from plants (i.e. alkaloids, phenolic compounds, saponines, etc.) are able to control plant diseases or, at least, to shape the microbial rhizosphere in favour of beneficial microbes thus helping the plant to overcome stress conditions (SUKUL, 1992; CHITWOOD, 2002; SOPPELSA et al., 2011; MocAli et al., 2015; LOMBARDI et al., 2018). Many of the discovered biologically active phytochemicals are considered safer to humans and environment than conventional pesticides (CHITWOOD, 2002). Among them, tannins play a significant role in numerous ecological processes (KRAUS et al., 2003), protect plants against herbivores (FEENY, 1976) and are toxic for numerous bacteria, fungi and yeasts (SCALBERT, 1991). Additionally, tannins are a group of water-soluble polyphenolic compounds that have the ability to precipitate proteins (BATE-SMITH \& SWAIN, 1962). They are found in higher plants mainly grouped into two classes, termed condensed and hydrolyzable tannins. Both classes have been shown to possess nematicidal activity (MiAn \& RodRigUEZ-KABANA, 1982; MOHAMED et al., 2000; NAZ et al., 2013), and termed condensed have been shown to inhibit gastrointestinal nematodes (BUTTER et al., 2001, ATHANASIADOU et al., 2001; Hoste et al., 2006). Several studies demonstrated that tannins inhibit microbial activity (BALDWIN et al., 1983; BENOIT \& STARKEY, 1968a; b; BENOIT et al., 1968; FIERER et al., 2001; HARRISON, 1971; LEWIS \& StARKeY, 1968; SChimel et al., 1996; 1998; SCHULz et al., 1992), whereas much more remains to be investigated about their effects on other soil biota such as plant parasitic nematodes (KRAUS et al., 2003). HeWLETT et al. (1997) suggest that the behavioural response of different nematode species to tannic acid is variable. In their studies, tannic acid was attractive for Meloidogyne arenaria (Neal) Chitw. and M. incognita (Kofoid \& White) Chitw., whereas it was repellent for Radophulus similis (Cobb) Thorne and no effects were observed on Heterodera glycines Ichinohe. In literature, tannins from chestnut have been reported to affect plant parasitic nematodes (BADRA \& ELGINDI, 1979; Hewlet et al., 1997; MAISTRELlo et al., 2010). Soil treatments with tannic acid were found to control $M$. arenaria on squash (Mian \& RodriguEZ-KabAnA, 1982). A previous 
formulation of tannins extracted from chestnut wood (brand name SaviotaN ${ }^{\circledR}$ ) has been tested on M. javanica and on Globodera rostochiensis (Woll.) Skarbilovich at concentrations ranging from 0.32 to $20.48 \mathrm{~g} \mathrm{~L}^{-1}$ (MAISTRELLO et al., 2010; RENČO et al., 2012), and on eggs and juveniles of M. incognita at two concentrations $\left(2\right.$ and $\left.5 \mathrm{~g} \mathrm{~L}^{-1}\right)$ showing a nematostatic action and an inhibitory effect on eggs hatching (CARletti \& Maistrello, 2012). However, these authors have used a different formulation of Saviota ${ }^{\circledR}$ and higher concentrations of application therefore their results are not comparable to our data. The objective of the present work was to evaluate the effect of a new formulation of SaviotaN ${ }^{\circledR}$ nutraceutical for crops (Gruppo Mauro Saviola s.r.l., Viadana, Italy) in wet powder (WP) containing $75 \%$ of pure tannins on the RKN Meloidogyne incognita both in vitro and in pot experiments on tomato under controlled conditions.

\section{MATERIAL AND METHODS}

\section{CHEMICALS}

The chestnut tannin extract Saviota $\mathrm{N}^{\circledR}$ was tested in seven doses ranging from 0.30 to $1.50 \mathrm{~g} \mathrm{~L}^{-1}$ as reported in Table 1. Fosthiazate $150 \mathrm{~g} \mathrm{~L}^{-1}$ (Nemathorin ${ }^{\circledR} 150 \mathrm{EC}$; Syngenta), abamectin $20 \mathrm{~g} \mathrm{~L}^{-1}$ (Tervigo ${ }^{\circledR}$ SC 1; Syngenta) and garlic extract, Allium sativum (L.), Allicin $<1 \mathrm{ppm}$ (Garland $^{\circledR}$; Omex Agriculture Ltd) were used for comparison at recommended doses.

Table 1-Schedule treatments and codes.

\begin{tabular}{cccc}
\hline \hline Treatment codes & Active ingredient & $\begin{array}{c}\text { Dose } \\
\mathrm{kg} / \mathrm{ha}^{-1}\end{array}$ & $\begin{array}{c}\text { Dose } \\
\mathrm{g} / \mathrm{L}^{-1} \mathrm{H}_{2} \mathrm{O}\end{array}$ \\
\hline T30 & Tannin WP 75\% & $6 \mathrm{~kg}$ & $0.30 \mathrm{~g}$ \\
T40 & Tannin WP 75\% & $8 \mathrm{~kg}$ & $0.40 \mathrm{~g}$ \\
T50 & Tannin WP 75\% & $10 \mathrm{~kg}$ & $0.50 \mathrm{~g}$ \\
T75 & Tannin WP 75\% & $15 \mathrm{~kg}$ & $0.75 \mathrm{~g}$ \\
T10 & Tannin WP 75\% & $20 \mathrm{~kg}$ & $1.00 \mathrm{~g}$ \\
T12 & Tannin WP 75\% & $25 \mathrm{~kg}$ & $1.25 \mathrm{~g}$ \\
T15 & Tannin WP 75\% & $30 \mathrm{~kg}$ & $1.50 \mathrm{~g}$ \\
Fost & Fosthiazate 150 g L & $10.0 \mathrm{~L}$ & $0.50 \mathrm{~mL}$ \\
Aba & Abamectin 20 g L-1 & $5.0 \mathrm{~L}$ & $0.25 \mathrm{~mL}$ \\
Garl & Allicin $<1 \mathrm{ppm}$ & $8.0 \mathrm{~L}$ & $0.25 \mathrm{~mL}$ \\
Cont & \multicolumn{4}{c}{ Water } \\
\hline
\end{tabular}

\section{IN VITRO EXPERIMENTS}

Second-stage juveniles (J2s) were obtained from an Italian population of $M$. incognita reared on tomato Solanum lycopersicum (L.) Karst. ex Farw. cv. Naxos in the greenhouse of the University of Naples Federico II. The Meloidogyne species used in our experiments have been morphological and molecular identified previously (D'ERRICO et al., 2014). Egg masses from infested tomato roots were collected and hatched by tap water to obtain J2s to use in the experiments. Freshly hatched J2s (24 hours old) were used. The irreversibility or reversibility of $\mathrm{J} 2 \mathrm{~s}$ mobility was determined by rinsing and shifting immobile nematodes to distilled water (GIACOMETTI et al., 2010; D'ERRICO et al., 2017a; D'ERRICO et al., 2017b). Forty J2s were added to individual wells, each containing the solution under assess- ment, then wrapped with parafilm and stored at $25 \pm 1^{\circ} \mathrm{C}$ in the dark. The J2s exposed to water served as controls. Nematodes were considered paralyzed when no movement could be observed after poking them with a needle during an observation period of $10 \mathrm{~s}$ and their number was recorded every $24 \mathrm{~h}$ for 28 days. Subsequently, immobile J2s were washed in distilled water to remove residuals and transferred, according to the different immobility times caused by each solution, in a new well containing only water under the above conditions. After exposure to water, the number of immobile J2s that became motile was also counted as previously described. J2s that did not recover their motility in water were considered dead. Mobility was observed using a stereomicroscope (Discovery V8; Zeiss, Germany). The experiment was performed twice and each treatment was replicated 4 times.

\section{IN VIVO EXPERIMENTS}

Pot experiments were done in a greenhouse located in Terlizzi (Bari, Italy), using $14 \mathrm{~cm}$ squared pots (height 10 $\mathrm{cm}$ and 3.6 L volume of soil) placed on soil surface covered with a polyethylene film. Pots were filled with uniformly and naturally infested soil by the same population of $M$. incognita used for in vitro experiments. This soil contains $4.0 \%$ clay, $52.0 \%$ silt and $44.0 \%$ sand (medium texture), and its texture is classified as silt loam (USDA) with $\mathrm{pH}$ of 7.8 and an organic matter content of $19 \mathrm{~g} \mathrm{~kg}^{-1}$. The initial nematode population was extracted by cotton-wool filter method for 48 hours at $22 \pm 2^{\circ} \mathrm{C}$ and then counted $(156 \mathrm{~J} 2 \mathrm{~s}$ per $10 \mathrm{~cm}^{3}$ of soil). Certified seedlings, grown in polystyrene alveolate trays (ø $2 \mathrm{~cm})$, were used. RKN susceptible tomato seedlings $\mathrm{cv}$. Naxos, with two true leaves stage with an uniform growth, were transplanted in pots and, immediately, treated. Control pots received only water. Irrigation and fertilization were homogeneously supplied according to crop needs. The final nematode population in soil was counted as reported above. All applications were manually carried out using a Becher. Three groups of treatments were conducted concurrently. The first group included 7 treatments of tannin extract (T30, T40, T50, T75, T10, T25 and T15) applied at transplant. The second group included 7 treatments of tannin extract (T30a, T40a, T50a, T75a, T10a, T25a and T15a) applied at transplant and 14 days after and the treatment was repeated every 7 days. The third group included 2 treatments of tannin extract (T10b and $\mathrm{T} 15 \mathrm{~b}$ ) applied at transplant and after 14 days. The tannin extract differently applied was compared to 4 additional treated and untreated control treatments (Fost, Aba, Garl and water) for a total of 20 treatments. Trial was performed for 60 days and treatments were arranged in a randomized complete block design with four replicates per treatment. The experiment was performed twice. The schedule treatments is described in Table 2.

\section{DATA ANALYSIS}

Data from the in vitro experiments were subjected to analysis of variance (ANOVA) and Fisher's least significant difference (LSD) tests using SPSS software (SPSS Statistics, v. 21 for Windows). For the in vivo experiments, plant heights were recorded at 30 days after transplanting (DAT) and 60 DAT, whereas root galling index (RGI) and final population density of nematodes were determined at 60 DAT from all plants. RGI was evaluated using the 0-10 scale where $0=$ no galling visible, $1=10 \%$ of the root system galled, $2=20 \%$ of the roots galled, etc., and $10=$ $100 \%$ galled roots (Bridge and Page, 1980). The effect of different treatments was examined using ANOVA and 
Table 2 - Codes identifying pot treatments and effects of different concentrations of aqueous solutions of tannins and treated and untreated controls on the root-knot nematode Meloidogyne incognita.

\begin{tabular}{|c|c|c|c|c|c|c|c|}
\hline \multirow[t]{2}{*}{ Treatment codes } & \multirow[t]{2}{*}{$\begin{array}{l}\text { Dose } \\
\text { at transplant } \\
\left(\mathrm{kg} / \mathrm{ha}^{-1}\right)\end{array}$} & \multirow[t]{2}{*}{$\begin{array}{c}\text { Dose } \\
\mathrm{g} / \mathrm{L}^{-1} \mathrm{H}_{2} \mathrm{O}\end{array}$} & \multirow[t]{2}{*}{$\begin{array}{l}\text { Application } \\
\text { time }\end{array}$} & \multicolumn{2}{|c|}{$\begin{array}{l}\text { Plant heights } \\
\qquad(\mathrm{cm})^{\mathrm{a}}\end{array}$} & \multirow[t]{2}{*}{$\begin{array}{l}\text { Nematodes } \\
10 \mathrm{~cm}^{3} \text { soil }^{\mathrm{b}}\end{array}$} & \multirow[t]{2}{*}{$\mathrm{RGI}^{\mathrm{c}}$} \\
\hline & & & & $30 \mathrm{DAT}$ & 60 DAT & & \\
\hline $\mathrm{T} 30$ & $6 \mathrm{~kg}$ & $0.30 \mathrm{~g}$ & \multirow{7}{*}{ at transplant } & $45.69 \mathrm{a}$ & $71.38 \mathrm{~b}$ & $607 \mathrm{a}$ & $5.25 \mathrm{a}$ \\
\hline $\mathrm{T} 40$ & $8 \mathrm{~kg}$ & $0.40 \mathrm{~g}$ & & $47.81 \mathrm{a}$ & $71.56 \mathrm{~b}$ & $595 \mathrm{a}$ & $5.13 \mathrm{a}$ \\
\hline $\mathrm{T} 50$ & $10 \mathrm{~kg}$ & $0.50 \mathrm{~g}$ & & $45.56 \mathrm{a}$ & $70.63 \mathrm{~b}$ & $597 \mathrm{a}$ & $5.13 \mathrm{a}$ \\
\hline $\mathrm{T} 75$ & $15 \mathrm{~kg}$ & $0.75 \mathrm{~g}$ & & $46.13 \mathrm{a}$ & $71.88 \mathrm{~b}$ & $596 \mathrm{a}$ & $5.19 \mathrm{a}$ \\
\hline $\mathrm{T} 10$ & $20 \mathrm{~kg}$ & $1.00 \mathrm{~g}$ & & $45.94 \mathrm{a}$ & $71.94 \mathrm{~b}$ & $586 \mathrm{a}$ & $5.13 \mathrm{a}$ \\
\hline $\mathrm{T} 12$ & $25 \mathrm{~kg}$ & $1.25 \mathrm{~g}$ & & $47.63 \mathrm{a}$ & $71.13 \mathrm{~b}$ & $590 \mathrm{a}$ & $5.19 \mathrm{a}$ \\
\hline $\mathrm{T} 15$ & $30 \mathrm{~kg}$ & $1.50 \mathrm{~g}$ & & $47.19 \mathrm{a}$ & $71.81 \mathrm{~b}$ & $585 \mathrm{a}$ & $5.06 \mathrm{a}$ \\
\hline T30a & $6 \mathrm{~kg}$ & $0.30 \mathrm{~g}$ & \multirow{7}{*}{$\begin{array}{l}\text { at transplant } \\
+2 \text { weeks later }\left(6 \mathrm{~kg} / \mathrm{ha}^{-1}\right) \\
+ \text { every } 1 \text { week }\left(6 \mathrm{~kg} / \mathrm{ha}^{-1}\right)\end{array}$} & $46.31 \mathrm{a}$ & $75.56 \mathrm{ab}$ & $458 \mathrm{c}$ & $4.69 \mathrm{ab}$ \\
\hline $\mathrm{T} 40 \mathrm{a}$ & $8 \mathrm{~kg}$ & $0.40 \mathrm{~g}$ & & $46.25 \mathrm{a}$ & $76.75 \mathrm{ab}$ & $454 \mathrm{c}$ & $4.56 \mathrm{ab}$ \\
\hline $\mathrm{T} 50 \mathrm{a}$ & $10 \mathrm{~kg}$ & $0.50 \mathrm{~g}$ & & $47.44 \mathrm{a}$ & $75.44 \mathrm{ab}$ & $457 \mathrm{c}$ & $4.50 \mathrm{ab}$ \\
\hline $\mathrm{T} 75 \mathrm{a}$ & $15 \mathrm{~kg}$ & $0.75 \mathrm{~g}$ & & $48.38 \mathrm{a}$ & $77.56 \mathrm{ab}$ & $457 \mathrm{c}$ & $4.31 \mathrm{ab}$ \\
\hline $\mathrm{T} 10 \mathrm{a}$ & $20 \mathrm{~kg}$ & $1.00 \mathrm{~g}$ & & $48.44 \mathrm{a}$ & $78.38 \mathrm{ab}$ & $451 \mathrm{c}$ & $4.50 \mathrm{ab}$ \\
\hline $\mathrm{T} 12 \mathrm{a}$ & $25 \mathrm{~kg}$ & $1.25 \mathrm{~g}$ & & $48.19 \mathrm{a}$ & $79.38 \mathrm{ab}$ & $450 \mathrm{c}$ & $4.44 \mathrm{ab}$ \\
\hline $\mathrm{T} 15 \mathrm{a}$ & $30 \mathrm{~kg}$ & $1.50 \mathrm{~g}$ & & $47.88 \mathrm{a}$ & $80.06 \mathrm{ab}$ & $448 \mathrm{c}$ & $4.38 \mathrm{ab}$ \\
\hline $\mathrm{T} 10 \mathrm{~b}$ & $20 \mathrm{~kg}$ & $1.00 \mathrm{~g}$ & \multirow{2}{*}{$\begin{array}{c}\text { at transplant } \\
+2 \text { weeks later }\left(10 \mathrm{~kg} / \mathrm{ha}^{-1}\right)\end{array}$} & $45.06 \mathrm{a}$ & $78.06 \mathrm{ab}$ & $511 \mathrm{~b}$ & $5.00 \mathrm{a}$ \\
\hline $\mathrm{T} 15 \mathrm{~b}$ & $30 \mathrm{~kg}$ & $1.50 \mathrm{~g}$ & & $45.19 \mathrm{a}$ & $78.69 \mathrm{ab}$ & $500 \mathrm{~b}$ & $5.06 \mathrm{a}$ \\
\hline Fost & $10.0 \mathrm{~L}$ & $0.50 \mathrm{~mL}$ & at transplant & $46.50 \mathrm{a}$ & $89.75 \mathrm{a}$ & $371 \mathrm{~d}$ & $3.50 \mathrm{~b}$ \\
\hline Aba & $5.0 \mathrm{~L}$ & $0.25 \mathrm{~mL}$ & $\begin{array}{c}\text { at transplant } \\
+ \text { every } 2 \text { weeks }\left(5 \mathrm{~kg} / \mathrm{ha}^{-1}\right)\end{array}$ & $47.25 \mathrm{a}$ & $80.31 \mathrm{ab}$ & $381 \mathrm{~d}$ & $3.56 \mathrm{~b}$ \\
\hline Garl & $5.0 \mathrm{~L}$ & $0.25 \mathrm{~mL}$ & $\begin{array}{c}\text { at transplant } \\
+ \text { every } 2 \text { weeks }\left(11 \mathrm{~kg} / \mathrm{ha}^{-1}\right)\end{array}$ & $46.25 \mathrm{a}$ & $80.00 \mathrm{ab}$ & $390 \mathrm{~d}$ & $3.94 \mathrm{ab}$ \\
\hline Cont & \multicolumn{3}{|c|}{ Water } & $46.81 \mathrm{a}$ & $69.69 \mathrm{~b}$ & $621 \mathrm{a}$ & $5.25 \mathrm{a}$ \\
\hline
\end{tabular}

${ }^{a}$ Plant heights were determined at 30 DAT and 60 DAT.

${ }^{\mathrm{b}}$ Final nematode population density of Meloidogyne incognita (Kofoid \& White) Chitwood in $10 \mathrm{~cm}^{3}$ soil was extracted by cotton-wool filter method. ${ }^{\circ}$ Nematode root galling index (RGI) was obtained using a $0-10$ scale where $0=$ no galls and $10=100 \%$ of roots galled. Data are arithmetic means of four replications and means separated with the Student-Newman-Keuls test $(\mathrm{P}<0.05)$.

means were compared using Student-Newman-Keuls multiple comparison test. The level of significance was set at $P$ $<0.05$ in all the analyses.

\section{RESULTS}

\section{IN VITRO EXPERIMENTS}

The effect of each solution on J2s mobility is shown in Fig. I. Although the J2s mobility has been daily observed for 28 days, in Fig. I are reported only the most representative days. After 24 h, Fost demonstrated high nematotoxic activity with $90 \%$ of nematode immobility, Aba $25 \%$ of nematode immobility and three concentrations of tannin extract (T75, T12 and T15) immobilized $5 \%$ of J $2 \mathrm{~s}$. Whereas no nematicidal activities in the other tannin extract concentrations (T30, T40, T50, T10) and Garl solution were observed. After $48 \mathrm{~h}$ of exposition to each solution tested, the nematicidal activity on $\mathrm{J} 2 \mathrm{~s}$ of Garl was up to $30 \%$, Fost $92 \%$ and $\mathrm{Aba} 80 \%$ while the concentrations of tannin extract $\mathrm{T} 12$ and $\mathrm{T} 15$ were below to $15 \%$, and $\mathrm{T} 40, \mathrm{~T} 75$ and $\mathrm{T} 10$ were around $5 \%$; no effects on $\mathrm{J} 2 \mathrm{~s}$ exposed to T30 and T50 were observed. After 72 h, Fost caused the highest immobility (100\%) of J2s, Aba 90\%, Garl 50\% and still no effects of T30 on J2s mobility was observed, while immobile $\mathrm{J} 2 \mathrm{~s}$ exposed to all the other concentrations of tannin extract were $\leq$ to $20 \%$. The immobilization of J 2 s exposed to tannin extract increased over time and about $50 \%$ in T30, $\mathrm{T} 75, \mathrm{~T} 10, \mathrm{~T} 12$ and $\mathrm{T} 15$ solutions of $\mathrm{J} 2 \mathrm{~s}$ were immobilized within 10 days, except for T50 (45\%). The best performance at 10 days was shown by T40 (70\%). Overall, during 10 days of experiment, all the solutions tested were statistically different compared to the untreated control (water). However, the nematode mobility in tannin extract at different concentrations was still lower than all the other solutions. During the first two weeks, viability of juveniles was suppressed in Garl solution and tannic extract at the highest concentration (T15). All concentrations with tannins from 0.30 to $1.2 \mathrm{~g} \mathrm{~L}^{-1}$ showed a nematode immobility in the range of $60-70 \%$. A clear response of $\mathrm{J} 2 \mathrm{~s}$ to tannin extract was established from 15 to 20 days and a significant paralysis of J2s (up to $80 \%$ ) was evident after 20 days of exposure. At 25 days, all the J2s exposed to T30, T40, T50, T10 and T12 were immobilized. Results showed that the viability of $M$. incognita $\mathrm{J} 2 \mathrm{~s}$ was significantly reduced $(P<0.05)$ over time by all concentrations of tannin extract throughout the experiment but slowly and in different ways. All the concentrations of tannin extract $(0.30,0.40,0.50,0.75,1.00,1.25$, $1.50 \mathrm{~g} \mathrm{~L}^{-1}$ ) had significant effects on J2 immobility compared to the water control. However, differences between some tannin extract concentrations were not found.

In the subsequent experiment (Fig. II), the immobile 


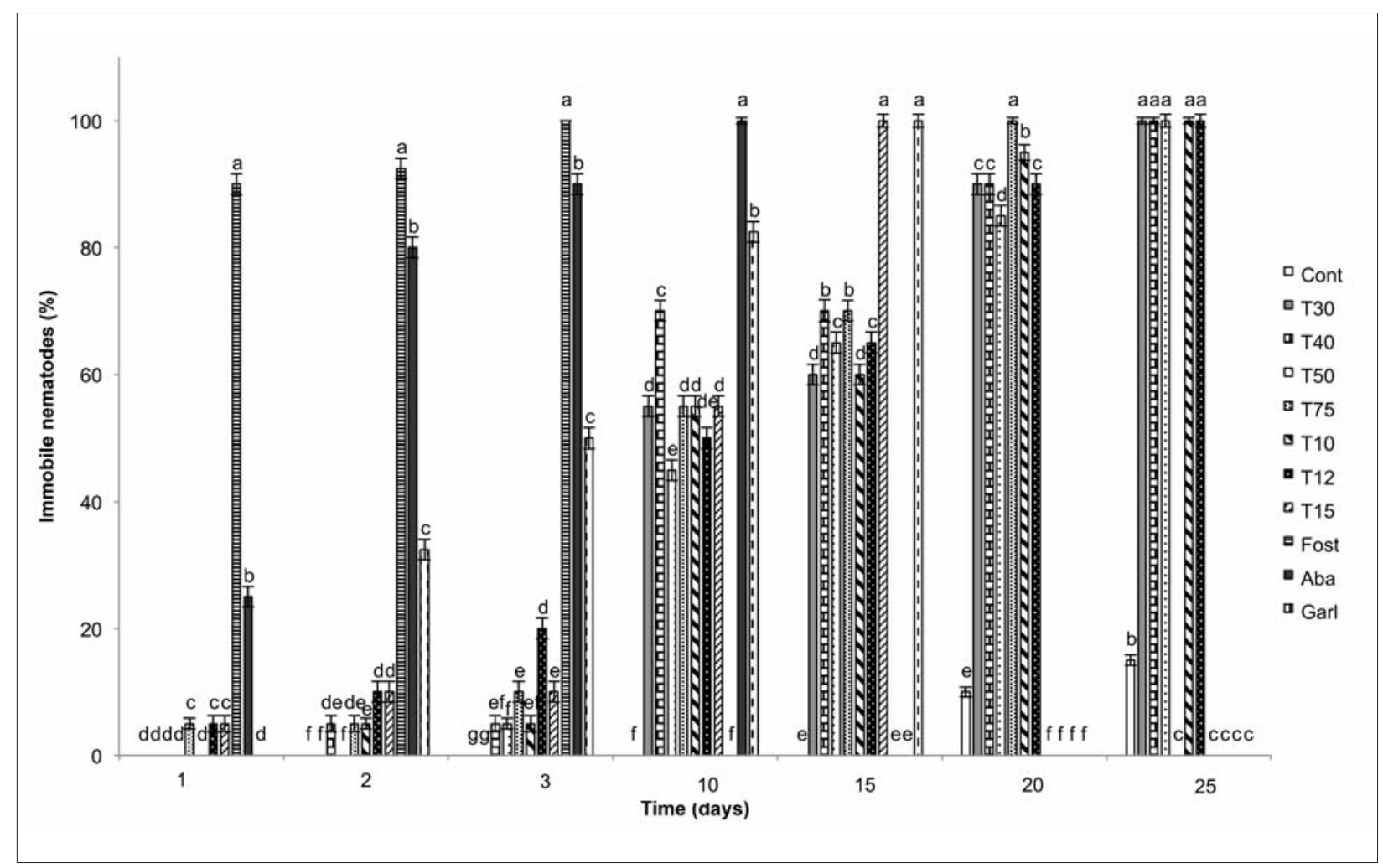

Fig. I - Percentage of immobile Meloidogyne incognita [(Kofoid \& White) Chitwood] second-stage juveniles (J2s) after exposure to seven concentrations of tannin extract from 0.30 to $1.50 \mathrm{~g} \mathrm{~L}^{-1}$ (T30, T40, T50, T75, T10, T25 and T15) and treated (Fost, Aba and Garl) and untreated (Cont, water) controls over time (days). Values are means of four replicates $\pm \mathrm{SD}$.

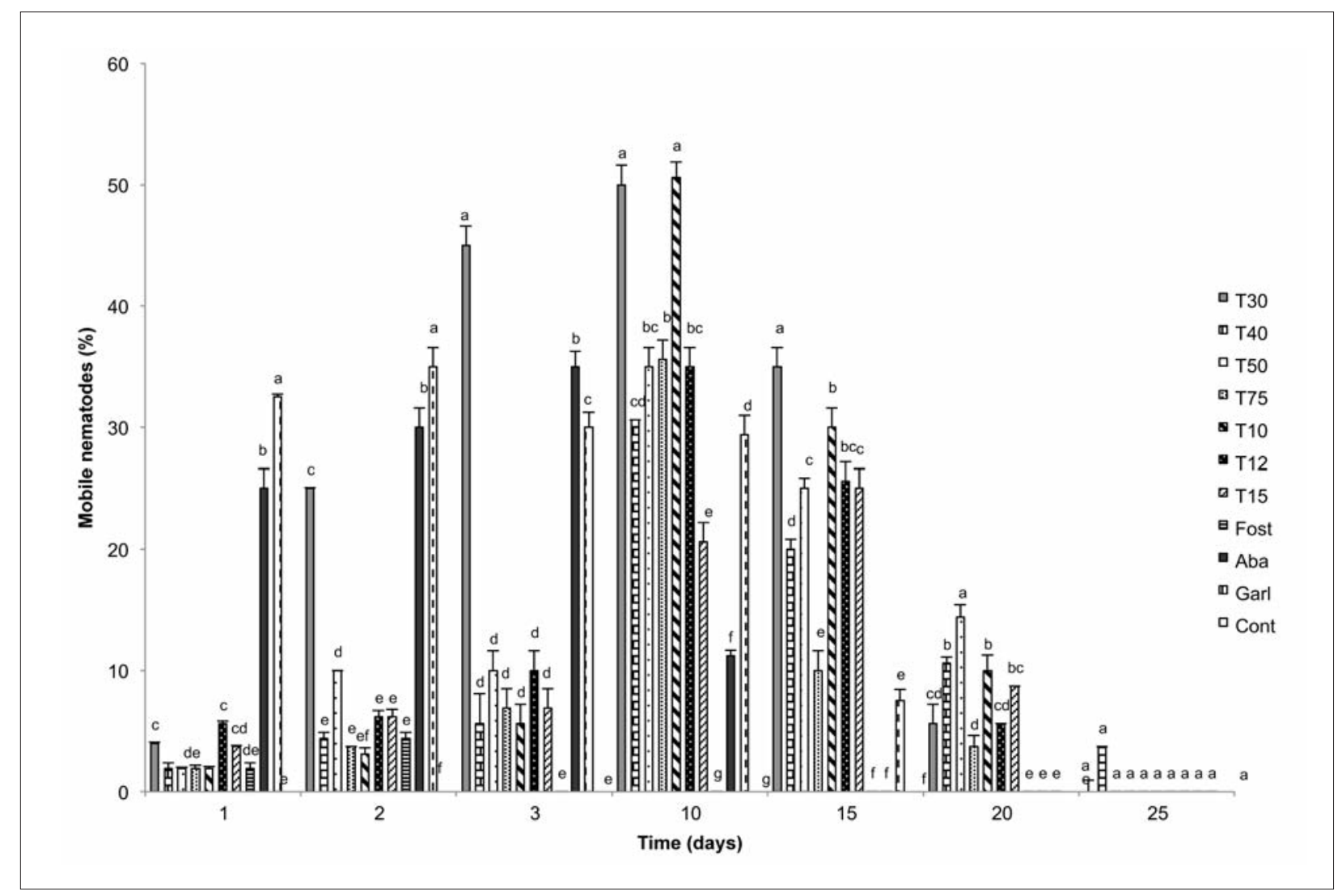

Fig. II - Cumulative percentage of mobile Meloidogyne incognita [(Kofoid \& White) Chitwood] second-stage juveniles (J2s) incubated in distilled water after exposure to seven concentrations of tannin extract from 0.30 to $1.50 \mathrm{~g} \mathrm{~L}^{-1}$ (T30, T40, T50, T75, T10, T25 and T15) and treated (Fost, Aba and Garl) and untreated (Cont, water) controls over time (days). Data are averages of four replicates. 
nematodes recovered their motility in water. This recovery was observed until J2s death. Generally, the mobility of J2s increased with exposure period to water. After exposure to the different concentrations of tannin extract, mobile $\mathrm{J} 2 \mathrm{~s}$ were in the range of $21 \%$ for T 15 to about $50 \%$ for T 30 and T10 after ten days rinse in water and these latter two concentrations (T30 and T10) were the highest peaks of recovery reached. Overall, the recovery in water of $\mathrm{J} 2 \mathrm{~s}$ previously immobilized by different concentrations of tannin extract (T30, T40, T50, T75,T10 and T15) was delayed in comparison with Aba and Garl and there were still alive J2s during an observation period of 25 days but it was not statistically significant. J2s immobilized by Garl also recovered their motility in water until death at 15 days. Only 4\% of $\mathrm{J} 2 \mathrm{~s}$, pre-exposed to Fost, recovered their motility just for two days; also, J2s pre-exposed to Aba recovered their motility but this recovery was shorter (until 10 days) than J2s pre-exposed to tannin extract and garlic extract. However, all J2s tested died gradually in time. The low percentage of $\mathrm{J} 2 \mathrm{~s}$ died in the control was considered physiological.

\section{IN VIVO EXPERIMENTS}

All 20 treatments did not significantly increased plant heights compared to the untreated control at 30 DAT (Table 2 ). Whereas, plant heights measured at 60 DAT were statistically different among treatments. The treated plants belonging to the first group (T30, T40, T50, T75, T10, T25 and T15) were not statistically different within them and in comparison to the untreated control (water). Also the treated plants belonging to the second group (T30a, T40a, T50a, T75a, T10a, T25a and T15a) were not statistically different within them but only when compared to the untreated control. The same results were shown by plants belonging to the third group (T10b and T15b). There were no statistically significant differences between the second and the third group when compared to Aba and Garl treated plants. The highest plants were recorded in pots treated with Fost.

Treatments with tannin extract applied only at transplant did not significantly reduced RGI in comparison to untreated control. The second group of tannin treated plants reduced RGI in comparison to untreated control, but RGI resulted significantly higher than that recorded in Fost and Aba treated plants. The plants treated with Garl had the same RGI recorded for the second group of plants treated with tannin extract. The third group of tannin treated plants (T10b and T15b) had the same RGI recorded for the first group of tannin treated plants and for untreated control. When tannin extract was applied only at transplant (first group) did not reduced the soil nematode population compared to the control. Applications of tannin extract at transplant and two weeks later (T10b and $\mathrm{T} 15 \mathrm{~b})$ reduced the soil nematode population compared to the untreated control but less than the tannin extract treatments applied to the second group of plants and treated controls. However, the values of soil nematode population recorded in the second group of tannin treated plants were statistically higher than those in treated controls (Fost, Aba and Garl). No treatment showed any phytotoxic effects at the concentrations tested.

\section{CONCLUSIONS}

Phytochemicals can play an important role in the sustainable management of plant parasitic nematodes in organic and conventional systems (D'ADDABBo et al., 2014). The results of the present in vitro study revealed that the tannin extracts from C. sativa had effects on M. incognita J2s mobility. The immobility of nematodes increased with increasing concentration and longer exposure times. Likely, these factors were the main responsible for nematode control. The recovery of J2s mobility upon transfer to distilled water indicated that tannin extract caused, in the majority of cases, a reversible paralysis on $M$. incognita. However, although $\mathrm{J} 2 \mathrm{~s}$ may recover their mobility under laboratory conditions, likely they are too weak to locate host plant roots in the field (HAYDOCK et al., 2006).

In the pot experiment, the significant differences among the three application times demonstrated the positive effect of repeated tannin applications. Based on our results, the best treatment repetition regimen, irrespective of concentration, was the applications of tannin at transplant, 14 days after transplantation and then every 7 days, because we reached the highest nematicidal effect without phytotoxicity on tomato plants. Tannins applied once at transplant did not produced statistically different effects in comparison to the untreated control. However, repeated applications of tannins reduced disease parameters less than treated controls with exception of RGI in comparison to garlic extract. No effect of tannin extract on stimulation of tomato plant height was observed. Likely, the small differences detected on plant heights among treatments were due to the activity of nematodes that has contributed to malfunctioning of root system.

The tannins content in roots could be involved in passive plant defence working as chemical barriers in the roots for the nematode invasion (TAYLOR \& MURANT, 1966). It has been recognized that tannins may be chemical signals that Meloidogyne species utilize to recognize plant hosts and locate areas for root penetration (OHRI \& PANNU, 2010). Application of tannins to soil, in pre-planting and at planting, could move up the feeding oriented-behavior of J2s and disorient them spreading "fake" chemical signals aimed to a reduction in the root searching efficiency of J2s that would either prevent or delay their attack; also postplanting applications, via drench or via drip irrigation, could have similar effects. According to other authors, we suppose that the observed nematostatic effect of tannins combined with their characteristics of attractants might represent a possible strategy to control RKN (HEWLETT et al., 1997; MAistrello et al., 2010). Previous studies on the effects of tannins on plant parasitic nematodes reported a grave phytotoxicity to the host plant, instead we demonstrated that tannins at the tested concentrations are safe for tomato crop. However, the beneficial effect of natural phytochemicals is a promising area of nematode management (CHITWOOD, 2002) and tannins have great potential in environmentally friendly integrated pest management programs (ABID et al., 1997). In conclusion, the use of SaviotaN ${ }^{\circledR}$ appears promising for the control of $M$. incognita in sustainable agriculture. The best performance may be obtained with short-term crops, low nematode population densities and to supplement other control strategies such as conventional treatments. However, further information is needed to investigate the effect of tannins in field experiments using different nematode-crop combinations and soil types.

\section{REFERENCES}

Abid M., Choudhry M.I., Magbool M.A., Rahman A.U., 1997 - Preliminary screening of some plants and their nematicidal activity against Meloidogyne javanica. Nematol. Medit., 25, 155-7. 
Athanasiadou S., KyriazaKis I., Jackson F., CoOP R.L., 2001 -Direct anthelmintic effects of condensed tannins towards different gastrointestinal nematodes of sheep: in vitro and in vivo studies. - Veterinary Parasitology, 99 (3), 205-219.

BADRA T., ElgINDI D.M., 1979 - The relationships between phenolic content and Tylenchulus semipenetrans populations in nitrogen-amended citrus plants. - Revue Nématol., 2: 161-164.

Baldwin I.T., Olson R.K., ReIners W.A., 1983 - Protein binding phenolics and the inhibition of nitrification in subalpine balsam fir soils. - Soil Biol. Biochem., 15: 419-423.

BATE-SMith E.C., SwAIN T., 1962 - Flavonoid compounds. In: Comparative Biochemistry, Mason H.S. \& Florkin A.M. Ed., Academic Press, New York, pp. 755-809.

BENOIT R.E, STARKEY R.L. 1968a - Inhibition of decomposition of cellulose and some other carbohydrates by tannin. Soil Sci., 105: 291-296.

BENOIT R.E, STARKEY R.L. 1968b-Enzyme inactivation as a factor in the inhibition of decomposition or organic matter by tannins. - Soil Sci., 105: 203-208.

BENOIT R.E, StARKEY R.L., BASARABA J., 1968 - Effect of purified plant tannin on decomposition of some organic compounds and plant materials. - Soil Sci., 105: 153-158.

BRIDGE J., PAGE S.L.R., 1980 - Estimation of root-knot nematode infestation levels on roots using a rating chart. - Trop. Pest Manage., 26: 296-298

ButTer N.L., DAWSON J.M., WAKelin D., ButTERY P.J., 2001 - Effect of dietary condensed tannins on gastrointestinal nematodes. - J. Agric. Sci. (Cambridge), 137: 461-469.

CARletti B., Maistrello L., 2012 - Il controllo dei nematodi nelle colture ortive: prove in vitro con i tannini di castagno. - I Georgofili, vol. 9: 338-344.

ChITwood D.J., 2002 - Phytochemical based strategies for nematode control 1. - Ann. Rev. phytopath., 40(1): 221-249.

D'Addabbo T., Laquale S., Lovelli S., Candido V., Avato P., 2014 -Biocide plants as a sustainable tool for the control of pests and pathogens in vegetable cropping systems. Italian Journal of Agronomy, 9(4): 137-145.

D’Addabbo T., Sasanelli N., Lamberti F., Carella A., 2000 - Control of root-knot nematodes by olive and grape pomace soil amendments. - Acta Hortic., 532: 53-57.

D'ERRICO G., CRESCENZI A., LANDI S., 2014 - First report of the southern root-knot nematode Meloidogyne incognita on the invasive weed Araujia sericifera in Italy. - Plant disease, 98: 1593.

D'Errico G., Giacometti R., Roversi P.F., D'ErRico F.P., Woo S.L., 2017a - Mode of Action and Efficacy of Iprodione against the Root-Knot Nematode Meloidogyne incognita. - Annals of Applied Biology, 171: 506-510.

D'Errico G., Marra R., Vinale F., LANDI S., Roversi P.F., Woo S.L., 2017b-Nematicidal efficacy of new abamectinbased products used alone and in combination with indolebutyric acid against the Root-Knot Nematode Meloidogyne incognita. - Redia, 100: 95-101. http://dx.doi.org/ 10.19263/REDIA-100.17.12

FEENY P., 1976 - Plant appearance and chemical defence. Recent Adv. Phytochem., 10: 1-40.

FIERER N., SCHIMEL J.P, CATES R.G, Zou Z., 2001 - The influence of balsam poplar tannin fractions on carbon and nitrogen dynamics in Alaskan taiga floodplain soils. - Soil Biol. Biochem., 33: 1827-1839.

FlanZy C., 2000 -Enologia: Fundamentos cientificos y tecnológicos. - Madrid España, Mundi-Prensa (Eds), pp. 389.

Ghorbani R., Wilcockson S., Koochek A., Leifert C., 2008 - Soil management for sustainable crop disease control: a review. - Environ. Chem Lett., 6: 149-62.
GIACOMETTI R., D’ERRICO G., D’ERRICO F.P., 2010 - In vitro nematicidal activity of the experimental formulation Tequil against Meloidogyne incognita and Heterodera daverti. Nematropica, 40: 263-268.

HARRISON A.F., 1971 - The inhibitory effect of oak leaf litter tannins on the growth of fungi, in relation to litter decomposition. - Soil Biol. Biochem., 3: 167-172.

Haydock P.J., Woods S.R., Grove I.J., Hare M.C., 2006 Chemical control of nematodes. In: Plant Nematology, Perry R.N. \& Moens M. Ed., cab International, Wallingford, UK, pp. 392-410.

Hewlett T.E., Hewlett E.M.. Dickson D.W., 1997 Response of Meloidogyne spp., Heterodera glycines and Radopholus similis to Tannic Acid. - J. Nematol., 29: 737741

Hoste H., Jackson F., Athanasiadou S., Thamsborg S.M., Hoskin S.O., 2006 - The effects of tannin-rich plants on parasitic nematodes in ruminants. - Trends in Parasitology, 22(6): 253-261.

Koul O., Walia S., Dhaliwal G.S., 2008 - Essential oils as green pesticides: Potential and constraints. - Biopestic. Int., 4: 63-84.

KRAUS T.E.C., DAHLGREN R.A., ZASOSKI R.J., 2003 - Tannins in nutrient dynamics of forest ecosystems - a review. - Plant and Soil, 256(1): 41-66.

LEWIS J.A., STARKEY R.L., 1968 - Vegetable tannins their decomposition and effects on decomposition of some organic compounds. - Soil Sci., 106: 241-247.

Lombardi N., Vitale S., TurRÀ D., Reverberi M., FANElli C., Vinale F., Marra R., Ruocco M., Pascale A., D'ERrico G., Woo S.L., Lorito M., 2018 - Root exudates of stressed plants stimulate and attract Trichoderma soil fungi. - Molecular Plant-Microbe Interactions. DOI10.1094/MPMI-12-17-0310-R

Maistrello L., VACCARI G., SASANElli N., 2010 - Effect of chestnut tannins on the root-knot nematode Meloidogyne javanica. - Helminthologia, 47(1): 48-57.

Mian I.H., RodrigueZ-Kabana R., 1982 - Survey of the nematicidal properties of some organic materials available in Alabama as amendments to soil for control of Meloidogyne arenaria. - Nematropica, 12(2): 235-246.

MiAn I.H., RodRIGUEZ-KABANA R., 1982a-Organic amendments with high tannin and phenolic contents for control of Meloidogyne arenaria in infested soil. - Nematropica, 12: 221-234.

Mian I.H., Rodriguez-Kabana R., 1982b - Survey of the nematicidal properties of some organic materials available in Alabama as amendments to soil for control of Meloidogyne arenaria. - Nematropica, 12: 205-220.

Mocali S., Landi S., Curto G., DellaValle E., Infantino A., Colzi C., D'Errico G., Roversi P., D’Avino L., LAZZERI L., 2015 - Resilience of soil microbial and nematode communities after biofumigant treatment with defatted seed meals. - Industrial Crops and Products, 75: 79-90.

Mohamed A.S.A., Mori T., Islam S.Q., SATO M., YAMASAKI T., 2000 - Lethal activity of gallo- and condensed tannins against the free-living soil-inhabiting nematode Caenorhabditis elegans. - J. Pesticide Sci., 25: 410-415.

Naz I., Palomares-Rius J.E., Blok V., Khan M.R., Ali S., 2013 - In vitro and in planta nematicidal activity of Fumaria parviflora (Fumariaceae) against the southern root-knot nematode Meloidogyne incognita. - Plant Pathology, 62(4): 943-952.

Nico A.I., JimÉnEZ-Diaz R.M., CASTILlo P., 2004 - Control of root-knot Nematodes by composted agro-industrial wastes in potting mixtures. - Crop Protection, 23: 581-587.

OHRI P., PANNU, S.K., 2010 - Effect of phenolic compounds 
on nematodes - A review. - Journal of Applied and Natural Science, $2: 344-350$.

RAGOZZINO A., D'ERRICO G., 2011 - Interactions between nematodes and fungi: a concise review. - Redia, 94: 123125.

RenČO M., SAsAnelli N., PAPAJOVÁ I., MAistrello L., 2012 - Nematicidal effect of chestnut tannin solutions on the potato cyst nematode Globodera rostochiensis (Woll.) Skarbilovich. - Helminthologia, 49: 108-114.

RenČo M., Sasanelli N., Maistrello L., 2014 - Plants as natural sources of nematicides. Nematodes: Comparative Genomics, Disease Management and Ecological Importance. Chapter: Plants as Natural Sources of Nematicides, Davis L.M. Ed. NOVA Science publisher, New York, 115-141.

SCALBERT A., 1991 - Antimicrobial properties of tannins. Phytochemistry, 30: 3875-3883.

SCHIMEL J.P, CATES R.G., RUESS R., 1998 - The role of balsam poplar secondary chemicals in controlling soil nutrient dynamics through succession in the Alaskan taiga.Biogeochemistry, 42: 221-234.
Schimel J.P, Van Cleve K., Cates R.G., Clausen T.P., REICHARDT P.B., 1996 - Effects of balsam poplar (Populus balsamifera) tannins and low molecular weight phenolics on microbial activity in taiga floodplain: soil implications for changes in N cycling during succession. - Can. J. Bot., 74: 84-90.

Schultz J.C, Hunter M.D., Appel H.M., $1992-$ Antimicrobial activity of polyphenols mediates plant-herbivore interactions. In: Plant Polyphenols. Synthesis, Properties, Significance. Hemingway R.W. \& Laks P.E. Eds., Plenum Press, New York, 621-637.

Soppelsa O., Giacometti R., D’ERrico G., D'Alessio M., 2011 -Effectivennes of soil solarization combined with a plant-derived formulation for the control of the root-knot nematode Meloidogyne incognita (Kofoid et White) Chitw. in greenhouse tomato. - Redia, 44: 163-166.

SUKUL N.C., 1992 - Plants antagonistic to plant-parasitic nematodes. - Indian Review of Life Sciences, 12: 23-52.

TAYlor C.E., Murant A.F., 1966 - Nematicidal activity of aqueous extracts from raspberry canes and roots. Nematologica, 12(4): 488-494. 
60 - Blank Page 